\title{
Intra-habitat heterogeneity of environmental factors regulating bacterioplankton community composition in Lake Taihu, China
}

\author{
Peng Xing ${ }^{1,2}$, Fanxiang Kong ${ }^{1, *}$ \\ ${ }^{1}$ Nanjing Institute of Geography and Limnology, Chinese Academy of Sciences, No. 73 East Beijing Road, \\ Nanjing 210008, PR China \\ ${ }^{2}$ Graduate School of the Chinese Academy of Sciences, Beijing 100039, PR China
}

\begin{abstract}
To investigate the intra-habitat heterogeneity of environmental factors that may have an impact on the bacterioplankton community composition (BCC), a 1 yr observation was done at 2 study sites in Lake Taihu, a large shallow eutrophic lake in China. One site was located at the center of Meiliang Bay, the other site was near the central region of the lake. Denaturing gradient gel electrophoresis (DGGE) of PCR-amplified partial 16S rRNA gene fragments was applied to analyze BCC. The unweighted pair group method with arithmetic mean (UPGMA) was used to investigate differences among BCC. Redundancy analyses (RDA) of the gel patterns, in relation to the physical, chemical, and biological factors of the 2 sites, were performed. Differences between the samples in Meiliang Bay and the lake center were evident during all periods. Four variables (the biomass of Microcystis spp., chl a, dissolved inorganic phosphorus [DIP], and water turbidity) were most strongly correlated with the bacterioplankton DGGE patterns. Particularly, significant intra-habitat heterogeneity of the environmental factors was detected. In Meiliang Bay, seasonal variations in DIP concentration had a profound impact on the composition of bacterioplankton communities, while in the lake center, wind-induced frequent sediment resuspension was an important reason for the variations in BCC. The inherent intra-habitat heterogeneity of environmental conditions is essential to maintain the heterogeneity of BCC at the 2 study sites.
\end{abstract}

KEY WORDS: Bacterioplankton community composition · Denaturing gradient gel electrophoresis • DGGE $\cdot$ Environmental factors $\cdot$ Redundancy analysis $\cdot$ RDA $\cdot$ Intra-habitat heterogeneity $\cdot$ Lake Taihu

\section{INTRODUCTION}

Lake Taihu, China, is a large shallow lake (maximum length $68.5 \mathrm{~km}$, maximum width $56 \mathrm{~km}$, maximum depth $2.6 \mathrm{~m}$ ) with a limited stock of submerged macrophytes, high turbidity, and large amounts of colonial cyanobacteria Microcystis spp. (Qin et al. 2004). The lake can be divided into several regions according to spatial differences in physical-chemical conditions and the plankton community structure. Meiliang Bay (surface area of ca. $100 \mathrm{~km}^{2}$ ) is one of the most eutrophic regions on the northern part of the lake. Two main rivers, the Liangxi and Lujiang, connect to the bay, discharging effluents from the cities of Wuxi and Changzhou. The high nutrient load leads to an extremely productive phytoplankton population in this region. In the central region of the lake, low water transparency is largely caused by wind-induced sediment resuspension (Zhang et al. 2003). The sediment resuspension maintains high exchange rates of organic matter and inorganic nutrients between sediment, sediment pore water, and the water column.

Bacterioplankton plays a key role in the microbial community responsible for cycling nutrients in 
aquatic systems (Cotner \& Biddanda 2002). Numerous studies have focused on the regulation of bacterial communities by environmental factors at the biomass level (e.g. Tammert et al. 2005). Recently, the application of molecular biological tools suitable for ecological studies has led to a greatly increased investigation of microbial diversity and has sparked interest in determining the factors that constrain microbial community composition in terrestrial and aquatic systems (Muylaert et al. 2002, Schauer et al. 2003, Kisand \& Nõges 2004, Lindström \& Bergström 2005). Previous work in Lake Taihu (Wu et al. 2007) showed that intra-habitat heterogeneity of the microbial food web structure is inherent in this lake. In Meiliang Bay, nutrient enrichment was identified as a main driving force for the microbial food web, while in the lake center, sediment resuspension was more critical. $\mathrm{Wu}$ et al. (2007) compared total bacterial and attached bacterial abundance and biomass between sites in Meiliang Bay and the lake center. However, little is known about the seasonal variation in bacterioplankton community composition (BCC) at the genetic level and whether distinct environmental factors affect the bacterioplankton community structure in different regions of the lake.

In the present study, we intended to relate $\mathrm{BCC}$ to environmental data and to reveal possible site-specific differences in the interaction between bacterial and environmental factors. Two study sites were selected in Lake Taihu: one at the center of Meiliang Bay and the other at the center of the lake. To follow the changes in $\mathrm{BCC}_{\text {, we }}$ used denaturing gradient gel electrophoresis (DGGE) of partial 16S rRNA gene fragments and the unweighted pair group method with arithmetic mean (UPGMA). The correlations between the patterns obtained and environmental factors were investigated using redundancy analysis (RDA).

\section{MATERIALS AND METHODS}

Study sites and sampling scheme. Water samples were collected monthly from April 2005 through March 2006 at 2 sites in Lake Taihu, China (Fig. 1). All samples were collected from surface waters (top $50 \mathrm{~cm}$ ) with a 2.51 Schindler sampler. Water samples $(50 \mathrm{ml})$ for determination of bacterial abundance were fixed with $2.0 \%$ formalin. Water for BCC analysis (500 ml) was kept in sterile bottles. Water samples (1 l) for identification and counts of phytoplankton and ciliates were preserved with $1.5 \%$ Lugol's iodine. Macrozooplankton was collected by filtering $10 \mathrm{l}$ of lake water through a $30 \mu \mathrm{m}$ nylon mesh and fixed with formalin (final concentration $4.0 \%$ ). All samples were stored at $4^{\circ} \mathrm{C}$ until further analysis.
Physical-chemical factor analyses. At each sampling, water temperature (Temp), $\mathrm{pH}$, conductivity (Cond), dissolved oxygen (DO), and water turbidity (Turb) were simultaneously measured by a YSI 6600 Multi-Parameter Water Quality Sonde. Dissolved organic carbon (DOC), total nitrogen (TN), ammonium $\left(\mathrm{NH}_{4}{ }^{+}-\mathrm{N}\right)$, nitrite $\left(\mathrm{NO}_{2}{ }^{-}-\mathrm{N}\right)$, nitrate $\left(\mathrm{NO}_{3}{ }^{-}-\mathrm{N}\right)$, total phosphorus (TP), ortho-phosphorus $\left(\mathrm{PO}_{4}{ }^{3-}-\mathrm{P}\right)$, and chlorophyll a ( $\mathrm{chl} \mathrm{a}$ ) were analyzed according to standard methods (Huang 1999).

Planktonic organism abundance and biomass. Phytoplankton samples were sedimented for $48 \mathrm{~h}$ prior to counting on a microscope. Phytoplankton species were identified according to $\mathrm{Hu}$ et al. (1980). Algal volumes were calculated from cell numbers and cell size measurements. Conversion to biomass assumes that $1 \mathrm{~mm}^{3}$ of volume is equivalent to $1 \mathrm{mg}$ of fresh weight biomass. Ciliates, rotifers, and cladocerans were counted according to standard methods (Huang 1999). For determination of total bacterial numbers, pre-fixed water samples were sonicated (Velji \& Albright 1993) and counted according to the method of Porter \& Feig (1980).

DGGE analyses of BCC. A $300 \mathrm{ml}$ subsample of water samples was sonicated to detach associated bacteria (Velji \& Albright 1993) and prefiltered with $3 \mu \mathrm{m}$ filters to remove phytoplankton and other large particles (Liu et al. 2000). The filtrate was then filtered through a $0.2 \mu \mathrm{m}$ pore size polycarbonate filter (Durapore ${ }^{\mathrm{TM}}$ Millipore) to collect bacterioplankton. The filters were stored at $-20^{\circ} \mathrm{C}$. Bacterial genomic DNA was extracted from the filters as previously described (Somerville et al. 1989).

16S rRNA gene fragments (approximately $550 \mathrm{bp}$ ) were amplified by PCR, using the bacterium-specific primer F341 (5'-CCTACGGGAGGCAGCAG) with a

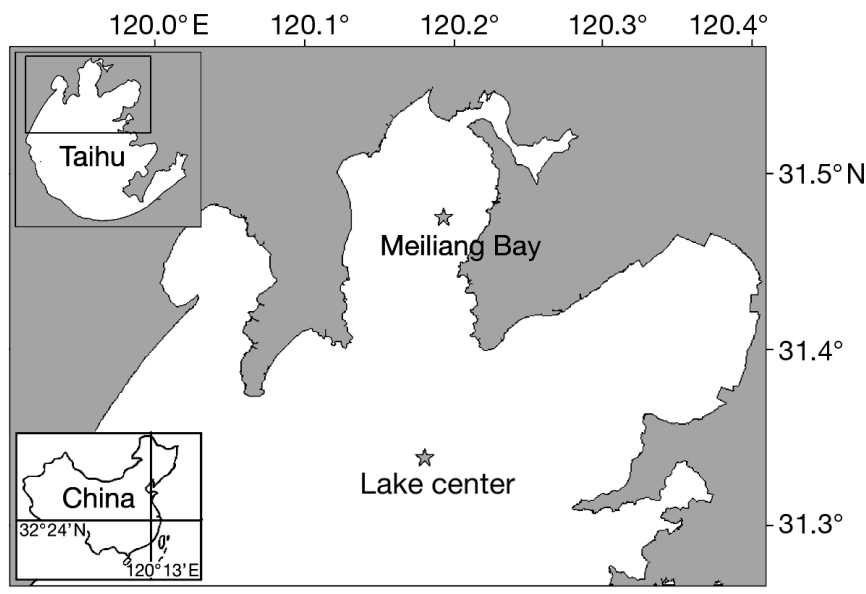

Fig. 1. Northern part of Lake Taihu, China, showing the sampling sites in Meiliang Bay and the lake center 
GC clamp (5'-CGCCCGCCGCGCCCCGCGCCCGTC CCGCCGCCCCCGCCCG) attached to its $5^{\prime}$ end and the universal primer R907 (5'-CCGTCAATTCCTTTRAGTTT). The volume of PCR mixtures was $50 \mu \mathrm{l}$ and contained $1 \times$ PCR buffer (containing $\mathrm{Mg}^{2+}$ ), $0.2 \mu \mathrm{mol} \mathrm{l}^{-1}$ of each primer, $200 \mu_{\mathrm{mol} \mathrm{l}} \mathrm{l}^{-1}$ of each dNTP, 2.5 U Taq DNA polymerase (Takara), 10 to $100 \mathrm{ng}$ of genomic DNA template, and DNase- and RNase-free water. Touchdown PCR was performed with an initial $5 \mathrm{~min}$ at $94^{\circ} \mathrm{C}$, followed by 30 cycles of $1 \mathrm{~min}$ at $94^{\circ} \mathrm{C}$, $1 \mathrm{~min}$ at 65 to $55^{\circ} \mathrm{C}$ (reducing the temperature by $1^{\circ} \mathrm{C}$ cycle $^{-1}$ for 10 cycles plus 20 cycles at $55^{\circ} \mathrm{C}$ ), and $1 \mathrm{~min}$ at $72^{\circ} \mathrm{C}$, followed by $5 \mathrm{~min}$ at $72^{\circ} \mathrm{C}$ (Muyzer et al. 1993). After PCR, the sizes of the products were verified on a $1.2 \%$ agarose gel.

A total of $800 \mathrm{ng}$ PCR product for each sample was loaded on a $6 \%$ (wt/vol) polyacrylamide gel (acrylamide and $N^{\prime} N^{\prime}$-methylene bisacrylamide at a ratio of $37.5: 1$ ) with a denaturing gradient that ranged from 50 to $70 \%$ (where $100 \%$ is defined as $7 \mathrm{~mol} \mathrm{l}^{-1}$ urea and $40 \%$ deionized formamide). Electrophoresis was performed with a DGGE-2001 system (CBS Scientific). The gel was run at $100 \mathrm{~V}$ for $16 \mathrm{~h}$ at $60^{\circ} \mathrm{C}$ in $1 \times \mathrm{TAE}$ running buffer $\left(40 \mathrm{mmol}^{-1}\right.$ Tris $[\mathrm{pH}=7.4], 20 \mathrm{mmol} \mathrm{l}^{-1}$ sodium acetate, $1 \mathrm{mmol} \mathrm{l^{-1 }}$ EDTA). The gels were stained with SYBR Green I (1:10 000 dilution, Molecular Probes) for $30 \mathrm{~min}$ and photographed with an Omega $^{\mathrm{TM}} 10$ Ultracam Gel Explorer. As standards, we used a mixture of DNA from 7 clones, obtained from a clone library of the 16S rRNA genes from one of the sites studied. On every gel, 2 standard lanes were loaded in parallel with our samples. Since these bands should always form at the same denaturant concentration in the gel, their positions were used to compare the patterns formed in different gels. All samples from each site were analyzed on 2 parallel DGGE gels.

Quantitative analysis of DGGE profiles. Gel images were analyzed with Gel-Pro Analyzer version 4.5 (Media Cybernetics). A densitometric curve was calculated for each gel track. In the following normalization step, 1 random standard lane was defined as the external reference pattern. Other standard lanes on each DGGE gel were aligned to this external reference pattern. The banding patterns of our samples were aligned gradually according to the alignment information provided by the standard lanes on the same gel. By aligning the bands of all references and sample lanes from every gel to the external reference pattern, it was possible to compare patterns from different gels to each other. Bands with a relative intensity of less than $0.2 \%$ were discarded. The DGGE profiles were analyzed in 2 ways:

(1) Pairwise similarity between gel banding patterns was calculated as $S_{\mathrm{D}}$ [Dice coefficient; $S_{\mathrm{D}}=\left(2 n_{\mathrm{AB}}\right) /\left(n_{\mathrm{A}}+\right.$ $n_{\mathrm{B}}$ ), where $n_{\mathrm{A}}$ is the total number of bands in gel $\mathrm{A}, n_{\mathrm{B}}$ is the total number of bands in gel $\mathrm{B}$, and $n_{\mathrm{AB}}$ is the number of bands common to gel $\mathrm{A}$ and gel $\mathrm{B}]$. For cluster analyses, similarity values were analyzed by UPGMA using the program MVSP version 3.0 (Kovach Computing Services).

(2) As a parameter for the structural diversity of the bacterial community, the Shannon-Wiener diversity index $H^{\prime}$ (Shannon \& Weaver 1971) was calculated using the following function:

$$
H^{\prime}=-\sum_{i=1}^{n} P_{i} \ln P_{i}
$$

where $P_{i}$ is the importance probability of the bands in a track. $P_{i}$ is calculated as $P_{i}=n_{i} / N$, where $n_{i}$ is the height of a peak and $N$ is the sum of all peak heights in the densitometric curve (Gafan et al. 2005).

Redundancy analyses. Multivariate statistics were applied to investigate the relation between BCC and the explanatory environmental variables. The software package CANOCO 4.5 for Windows (Microcomputer Power; ter Braak \& Šmilauer 2002) was used for all analyses. DGGE data were included as presence/ absence of bands. The tested abiotic environmental variables were Temp, Turb, $\mathrm{pH}$, Cond, DOC, TN, dissolved inorganic nitrogen (DIN; $\mathrm{NH}_{4}{ }^{+}-\mathrm{N}$ plus $\mathrm{NO}_{2}{ }^{-} \mathrm{N}$ plus $\mathrm{NO}_{3}{ }^{-} \mathrm{N}$ ), TP, dissolved inorganic phosphorus (DIP; $\mathrm{PO}_{4}{ }^{3-}-\mathrm{P}$ ), and chl $a$. The biotic variables included in the test were the biomass of phytoplankton and Microcystis spp., and the abundance of ciliates, rotifers, and cladocerans. RDA was performed by assuming linear species-environment relationships, because detrended correspondence analysis (DCA) ran on a DGGE profile matrix indicated that the length of the first axis was $<2$ (Lindström \& Bergström 2005). All environmental data were $\log (x+1)$ transformed except Temp and $\mathrm{pH}$. Environmental factors best describing the most influential gradients in community composition were identified by forward selection. The significance of the first ordination and canonical axes together was assessed with 499 unrestricted Monte Carlo permutations. A $t$-test was used to evaluate the differences of parameters between the 2 sites. Log-transformation was used to normalize the data if necessary.

\section{RESULTS}

\section{Major ecological differences at the 2 study sites}

The main ecological parameters measured at the 2 study sites during the $1 \mathrm{yr}$ observation are summarized in Table 1. The minimum water temperature was observed in January and the maximum in July at both sites. The average concentration of chl $a$ in Meiliang Bay was higher than that in the lake center, which was 
Table 1. Mean (range in parantheses) physical, chemical, and biological parameters determined for 2 the study sites in Lake Taihu, China, in the period from April 2005 through March 2006

\begin{tabular}{|c|c|c|c|}
\hline Environmental factor & Meiliang Bay & Lake center & $\begin{array}{l}\mathrm{p} \text { value } \\
(t \text {-test })\end{array}$ \\
\hline $\begin{array}{l}\text { Water temperature } \\
\left(\text { Temp, }{ }^{\circ} \mathrm{C}\right)\end{array}$ & $17.0(3.5-29.7)$ & $16.9(3.9-29.4)$ & 0.968 \\
\hline $\begin{array}{l}\text { Dissolved oxygen } \\
\left(\mathrm{DO}, \mathrm{g} \mathrm{m}^{-3}\right)\end{array}$ & $9.06(6.55-10.98)$ & $9.16(7.03-12.49)$ & 0.637 \\
\hline Conductivity (Cond, $\mu \mathrm{S} \mathrm{cm}^{-1}$ ) & $456(340-646)$ & $415(323-501)$ & 0.068 \\
\hline pH & $7.86(7.50-8.35)$ & $7.91(7.40-8.26)$ & 0.626 \\
\hline Water turbidity (Turb, NTU) & $54.7(23.0-115.0)$ & $62.5(38.0-140.0)$ & 0.300 \\
\hline $\begin{array}{l}\text { Dissolved organic carbon } \\
\left(\mathrm{DOC}_{1} \mathrm{mg} \mathrm{Cl}^{-1}\right)\end{array}$ & $8.53(6.17-10.24)$ & $8.48(6.68-11.51)$ & 0.909 \\
\hline Total nitrogen ( $\mathrm{TN}, \mathrm{mg} \mathrm{N}^{-1}$ ) & $3.54(2.13-6.25)$ & $2.55(1.27-5.17)$ & 0.000 \\
\hline $\begin{array}{l}\text { DIN }\left(\mathrm{NH}_{4}{ }^{-}-\mathrm{N} \text { plus } \mathrm{NO}_{2}^{-}-\mathrm{N}\right. \\
\left.\text { plus } \mathrm{NO}_{3}^{-}-\mathrm{N}, \mathrm{mg} \mathrm{N} \mathrm{l}^{-1}\right)\end{array}$ & $1.57(0.65-4.59)$ & $1.12(0.29-3.34)$ & 0.013 \\
\hline Total phosphorus (TP, $\mu g \mathrm{P} \mathrm{I}^{-1}$ ) & $225(61-348)$ & $180(48-268)$ & 0.005 \\
\hline DIP $\left(\mathrm{PO}_{4}{ }^{3-}-\mathrm{P}, \mu \mathrm{g} \mathrm{P} \mathrm{l}{ }^{-1}\right)$ & $8.61(1.68-24.02)$ & $5.14(1.73-18.47)$ & 0.005 \\
\hline Chl $a\left(\mathrm{mg} \mathrm{l}^{-1}\right)$ & $43.3(5.9-97.1)$ & $33.9(7.7-69.3)$ & 0.211 \\
\hline $\begin{array}{l}\text { Phytoplankton biomass } \\
\left(\mathrm{mg} \mathrm{l}^{-1}\right)\end{array}$ & $2.84(0.03-4.78)$ & $0.85(0.02-2.80)$ & 0.003 \\
\hline $\begin{array}{l}\text { Microcystis spp. biomass } \\
\left(\mathrm{mg} \mathrm{l}^{-1}\right)\end{array}$ & $1.13(0.0005-6.23)$ & $0.30(0.00024-1.93)$ & 0.144 \\
\hline $\begin{array}{l}\text { Total bacterial abundance } \\
\left(10^{6} \text { cells } \mathrm{ml}^{-1}\right)\end{array}$ & $7.48(3.31-13.40)$ & $5.73(2.11-7.94)$ & 0.008 \\
\hline DGGE band richness & $26.2(17-31)$ & $25.0(19-34)$ & 0.750 \\
\hline Shannon-Wiener index & $3.01(2.67-3.31)$ & $2.99(2.65-3.34)$ & 0.208 \\
\hline Ciliate abundance (cells ${ }^{-1}$ ) & $858(0-4800)$ & $317(100-900)$ & 0.158 \\
\hline Rotifer abundance (ind. $1^{-1}$ ) & $818(0-5200)$ & $109(0-500)$ & 0.086 \\
\hline $\begin{array}{l}\text { Cladoceran abundance } \\
\text { (ind. } 1^{-1} \text { ) }\end{array}$ & $170(0.8-1123)$ & $22.9(0.2-62.4)$ & 0.122 \\
\hline
\end{tabular}

Significant between-site differences were detected for the biomass of phytoplankton ( $\mathrm{p}<0.05)$. The biomass in Meiliang Bay was much higher than that in the lake center, ranging from $0.03 \mathrm{~g} \mathrm{~m}^{-3}$ in January to $4.78 \mathrm{~g} \mathrm{~m}^{-3}$ in October in Meiliang Bay. Microcystis spp. dominated in terms of biomass among the cyanobacteria, as well as the whole phytoplankton assemblages from May to November (Fig. 4c). In the lake center, the phytoplankton biomass ranged from $2.40 \times$ $10^{-4} \mathrm{~g} \mathrm{~m}^{-3}$ in December to $1.93 \mathrm{~g} \mathrm{~m}^{-3}$ in August. Microcystis spp. dominated phytoplankton communities in August and September (Fig. 4d).

In Meiliang Bay, the seasonal variation in ciliates was almost the same as that of rotifers (Fig. 4e). Both peaks of ciliates and rotifers formed in November. The highest abundance of cladocerans appeared in September, which was 2 mo earlier than the peaks of ciliates and rotifers. In the lake center, the highest abundance of ciliates and rotifers was found in October and November, respectively (Fig. 4f), which was similar to their variations in Meiliang Bay. The cladocerans contrary to the rule of water turbidity. Significant correlations between chl $a$ and water turbidity were observed in Meiliang Bay ( $r=0.675, p=0.016$, Fig. 2a). In the lake center, intensive fluctuation of water turbidity was apparent (Fig. 2b), and no evident correlation was identified between chl $a$ and water turbidity at this site $(\mathrm{r}=-0.015, \mathrm{p}=0.964)$.

The average concentrations of TN, DIN, TP, and DIP in Meiliang Bay were significantly higher than those in the lake center ( $p<0.05$, Table 1). In Meiliang Bay, the concentrations of DIN and DIP decreased at the end of August: DIN dropped to $0.2 \mathrm{mg} \mathrm{N}^{-1}$, DIP to around $4 \mu \mathrm{P} \mathrm{P}^{-1}$ (Fig. 3a,c). The peaks of DIN and DIP formed in March and February, respectively. In the lake center, DIN and DIP dropped to their lowest levels in September (Fig. 3b,d). Both then increased; the highest concentration of DIN appeared in January, and the highest DIP in February. At both sites, the ratios of DIP/TP constantly remained at a low level in summer and autumn and never exceeded $35 \%$ of TP during our sampling period. However, the ratios of DIN/TN covered a wider range. The ratios of DIN/DIP were characterized by high levels (Fig. 3e,f) at both sites. The annual mean of DIN/DIP in Meiliang Bay was much higher than that in the lake center. remained at low levels during our sampling period at this site. Although the averaged abundances of ciliates, rotifers, and cladocerans in the lake center were all lower than those in the Meiliang Bay, no significant differences were detected between the 2 sites.

\section{Variations in bacterioplankton community composition}

Pairwise similarities were calculated between the 2 parallel gels, which were loaded with the same samples. $S_{\mathrm{D}}$ were all high for the same samples on different gels $\left(S_{\mathrm{D}} \geq 0.973\right.$ for Meiliang Bay and $\geq 0.985$ for the lake center). In total, 52 bands of different positions were detected in the 12 samples from Meiliang Bay (Fig. 5a). The number of bands per sample averaged 26.2 and ranged from 17 to 31 . A total of 56 different bands and 19 to 34 distinct bands per sample were detected in the lake center (Fig. 5b). No significant difference in band richness was found between different gels.

Total bacterial abundance ranged from $3.31 \times 10^{6}$

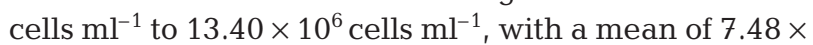
$10^{6}$ in Meiliang Bay. Bacterial numbers peaked in the middle of summer and dropped to the lowest level in 

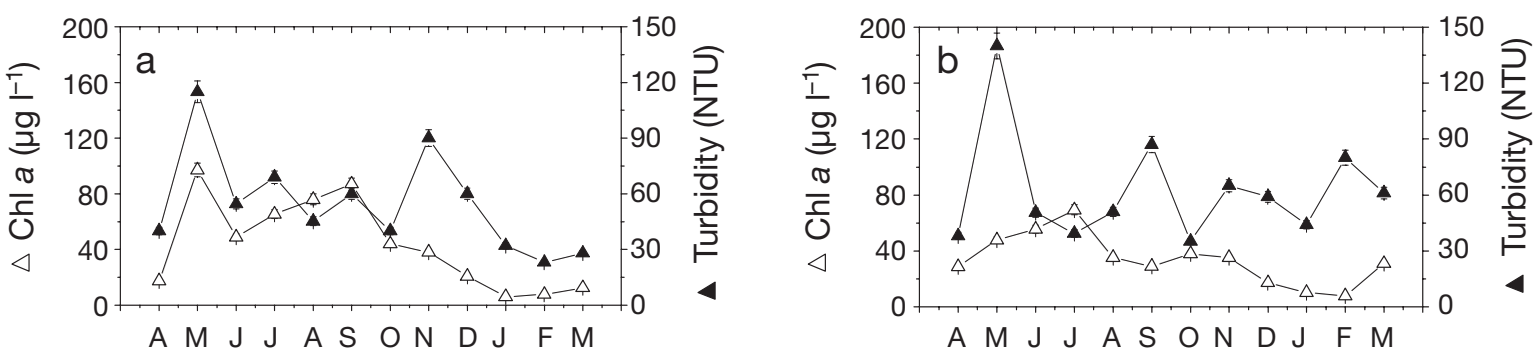

\section{Sampling time}

Fig. 2. Seasonal development of chl $a$ and water turbidity (Turb) in the water column at the 2 sampling sites in Lake Taihu: (a) Meiliang Bay and (b) the lake center
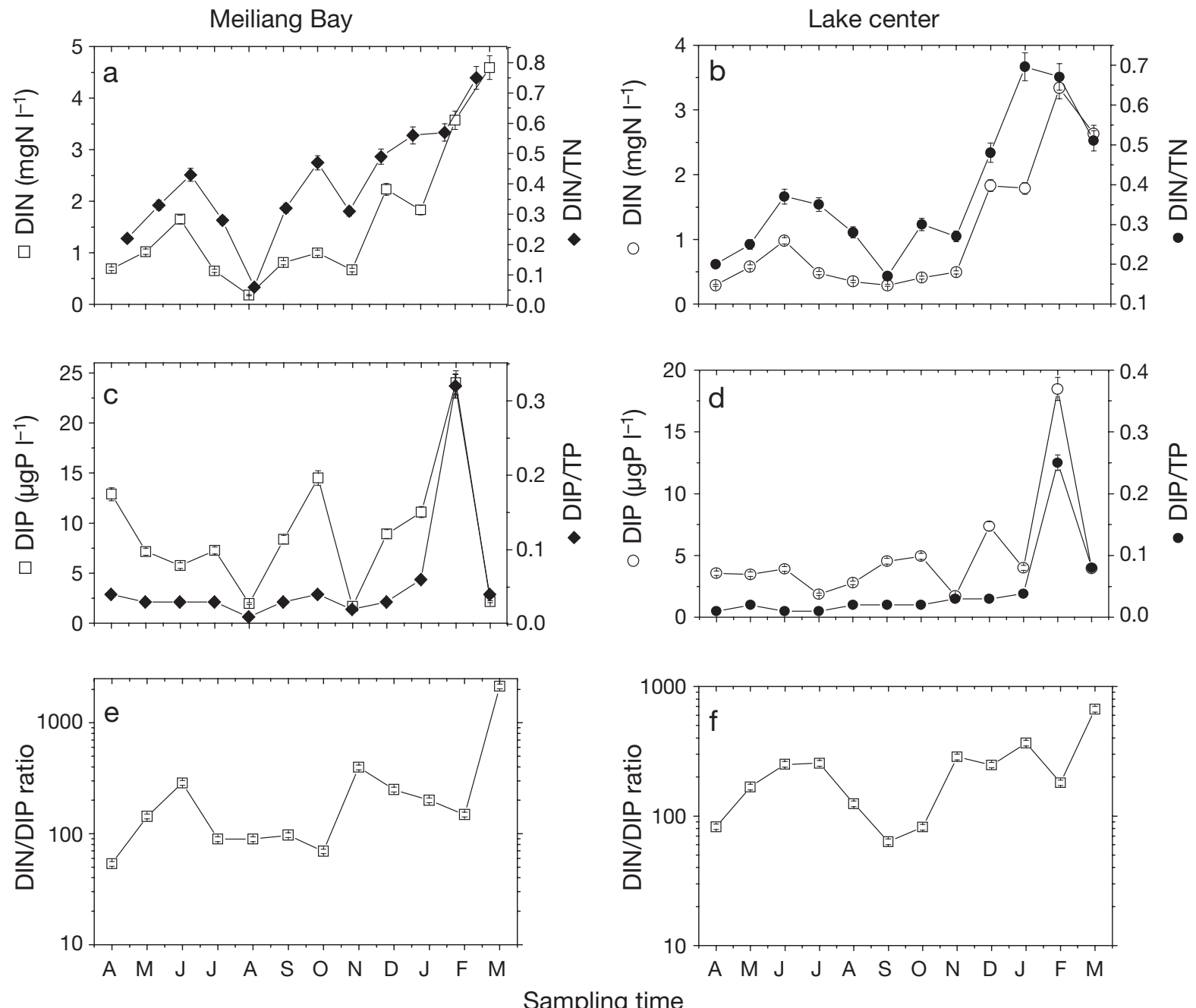

Fig. 3. Seasonal variations in $(\mathrm{a}, \mathrm{b})$ dissolved inorganic nitrogen (DIN) and the ratio of DIN to total nitrogen (DIN/TN), (c,d) dissolved inorganic phosphorus (DIP) and the ratio of DIP to total phosphorus (DIN/TP), and (e,f) the ratio of DIN/DIP at the 2 sampling sites in Lake Taihu

late winter. $H^{\prime}$ ranged from 2.77 to 4.41 with a mean of 3.01. No significant correlation was found between bacterial abundance and $H^{\prime}$ (Fig. 4a). In the lake center, the mean bacterial abundance was $5.73 \times 10^{6}$ cells

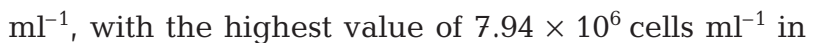
the middle of summer and the lowest value of $2.11 \times$ $10^{6}$ cells $\mathrm{ml}^{-1}$ in early winter. The annual mean of $H^{\prime}$ was a bit higher in the lake center than that in Meil- 

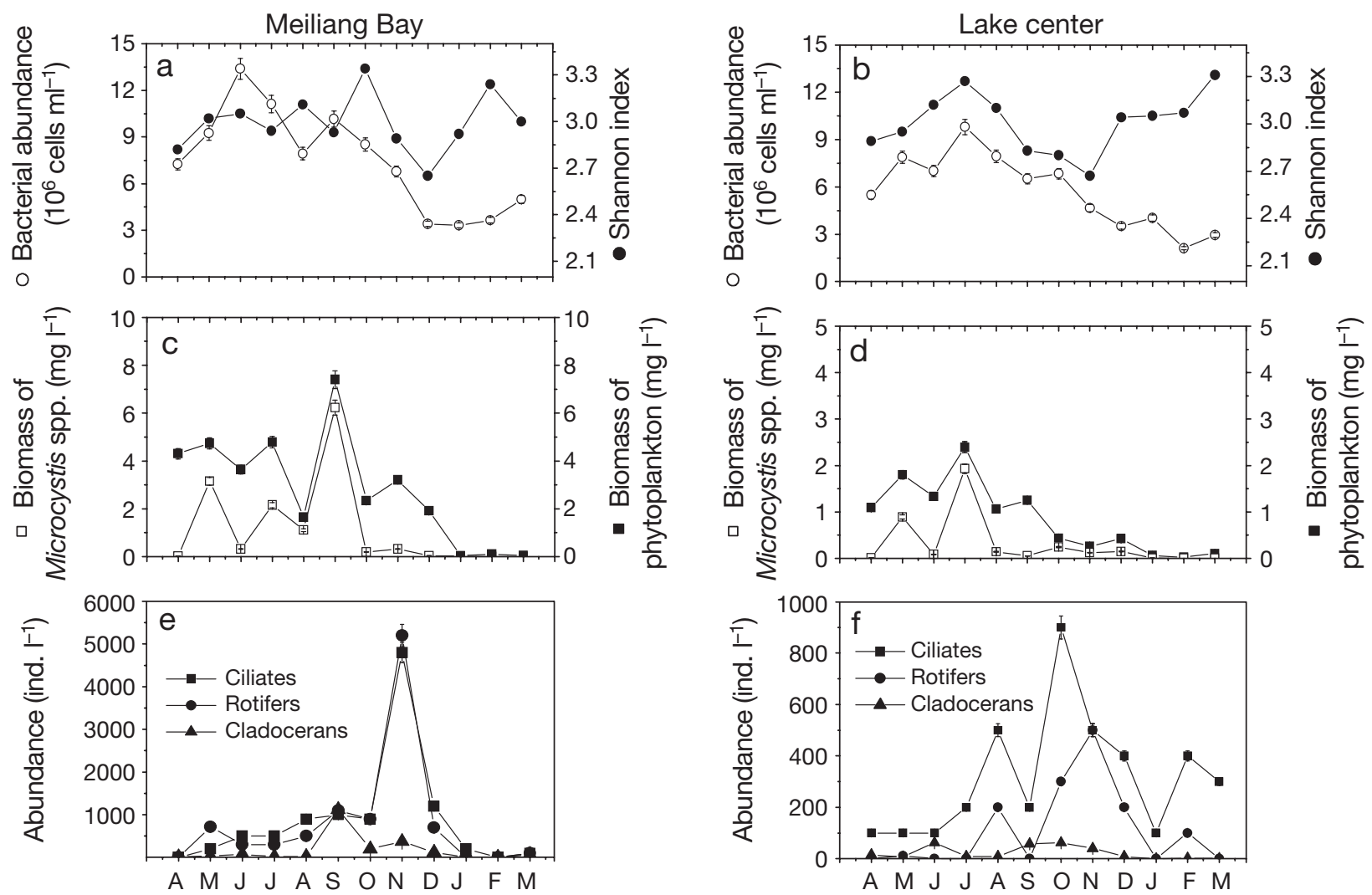

Sampling time

Fig. 4. Seasonal variations in (a,b) bacterial abundance and the Shannon-Wiener index, (c,d) biomass of Microcystis spp. and phytoplankton, and $(\mathrm{e}, \mathrm{f})$ individual abundances of ciliates, rotifers, and cladocerans at the 2 sampling sites in Lake Taihu

(a)

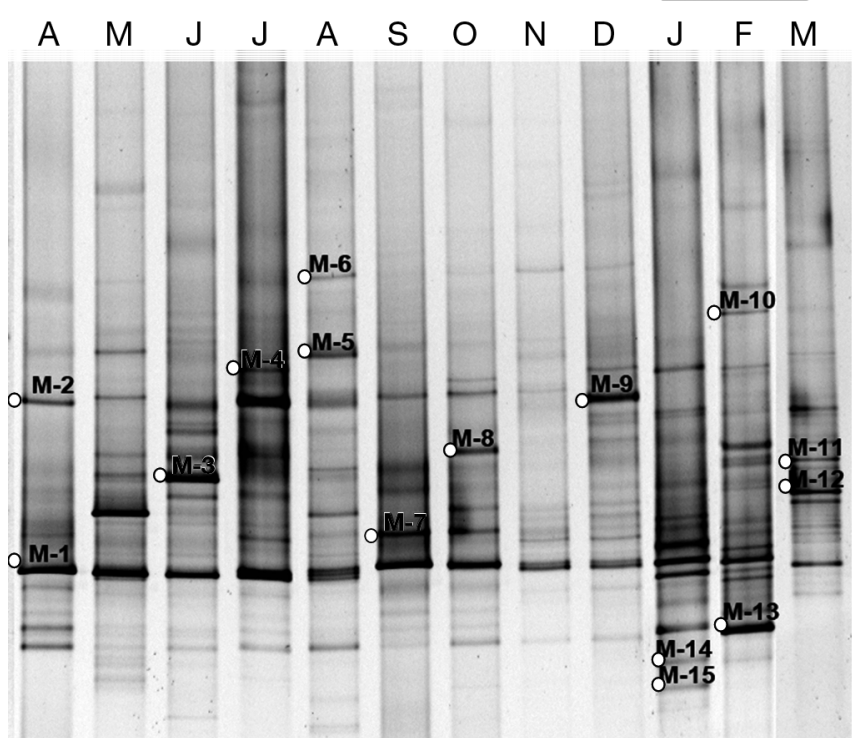

(b) 2005 2006
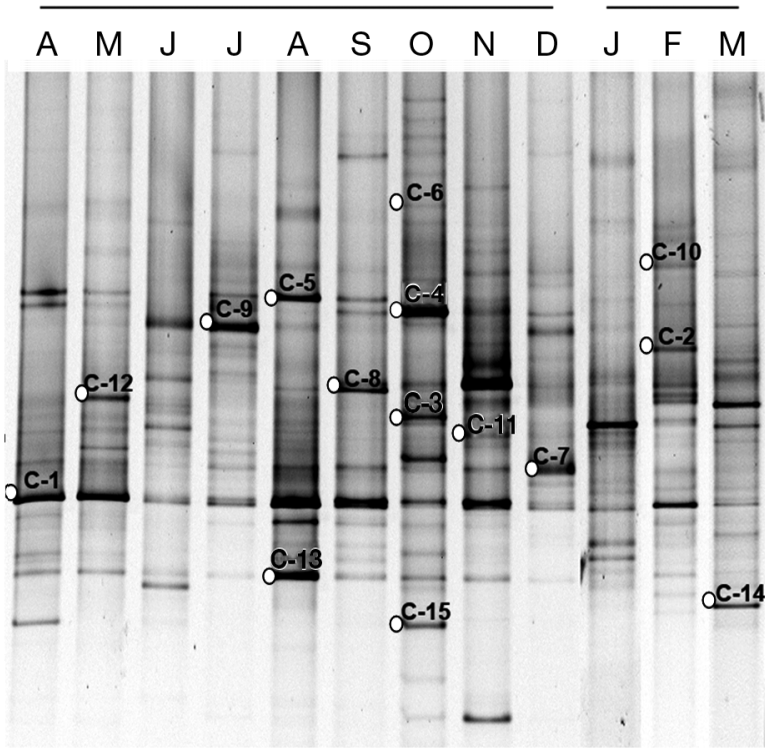

Fig. 5. Negative images of DGGE gels containing bacterial 16S rRNA gene fragments from the 2 sites in Lake Taihu: (a) Meiliang Bay and (b) the lake center. Representative bands that are comparable between the 2 sites are marked with open circles beside the bands. Their codes ( $\mathrm{M}$ or $\mathrm{C}$ followed by the band number) are above the bands. $\mathrm{M}$ and $\mathrm{C}$ : bands found in Meiliang Bay and the lake center, respectively. The same band numbers present in different gels indicate comparable positions 


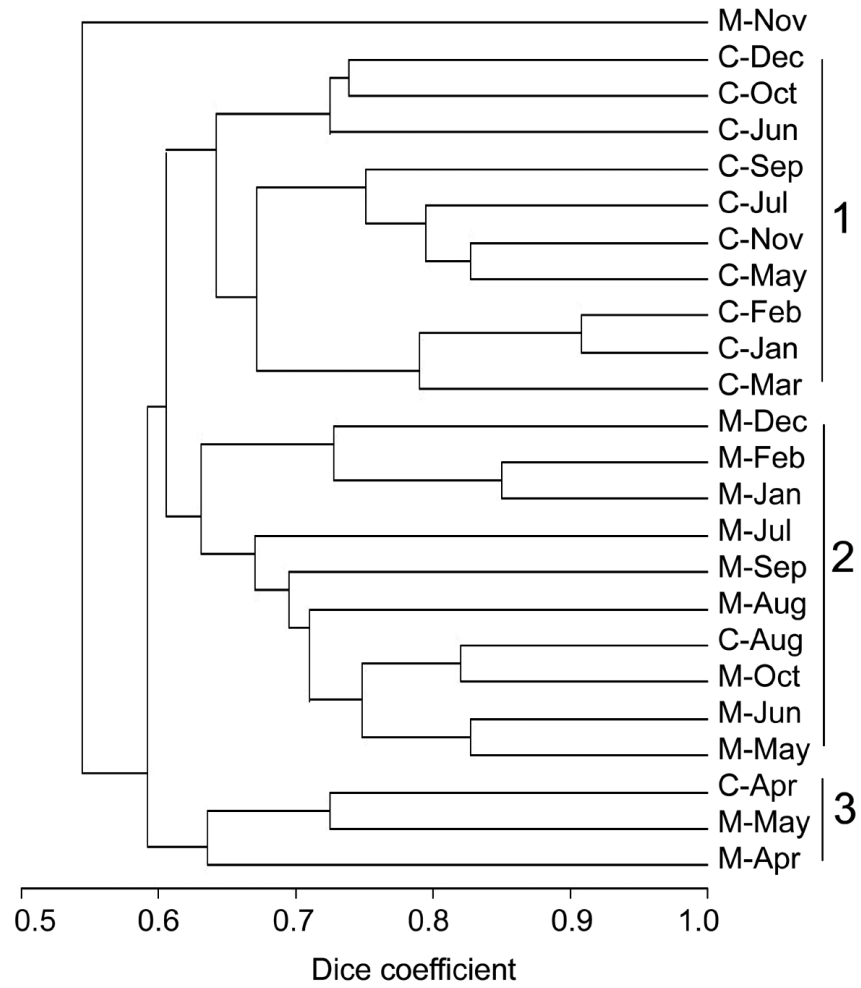

Fig. 6. UPGMA Dice distances dendrogram generated from DGGE profiles of 24 samples from the 2 sites in Lake Taihu. M and C: samples from Meiliang Bay and the lake center, respectively. Samples are grouped into 3 arbitrarily defined clusters $(1,2$, and 3$)$

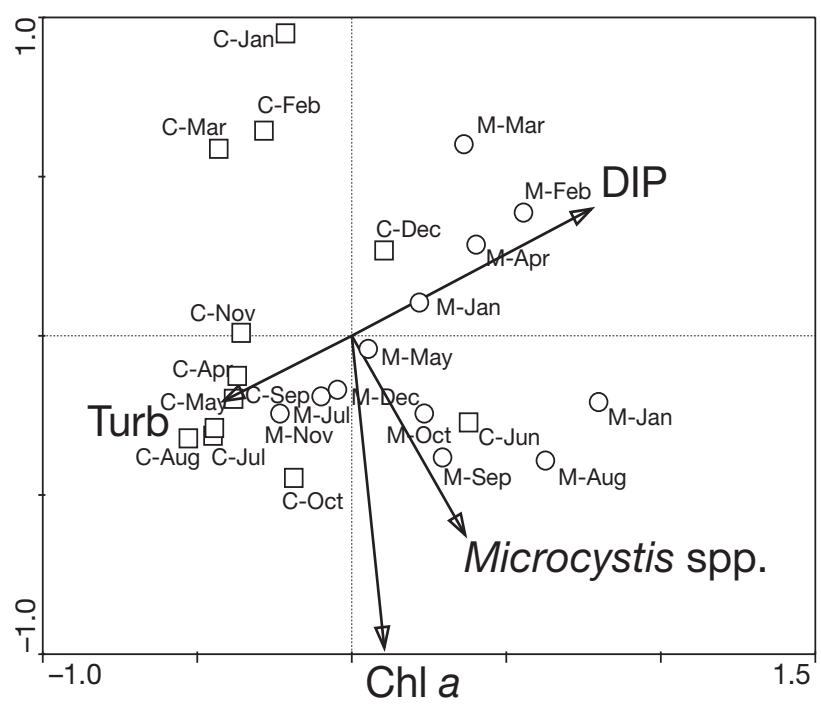

Fig. 7. Redundancy analysis biplot showing different bacterial communities in relation to the strongest environmental factors at the 2 study sites in Lake Taihu. Samples collected from Meiliang Bay $(M, O)$ and the lake center $(C, \square)$. Sample codes ( $\mathrm{M}$ or $\mathrm{C}$ followed by the sampling time) are adjacent to the symbols iang Bay. The fluctuation in bacterial abundance was significantly correlated with the $H^{\prime}$ during April to October $(r=0.766, p=0.040)$, while no evident correlation was found from November to March (Fig. 4b).

Distinct spatial differences were evident in the UPGMA dendrogram of BCC (Fig. 6). Samples were grouped into 3 arbitrarily defined clusters. Cluster 1 contained only samples from the lake center. Cluster 2 was composed of samples from Meiliang Bay except the August sample from the lake center. Cluster 3 included 3 samples: April and May samples collected from Meiliang Bay and the April sample from the lake center. The November sample from Meiliang Bay was dissimilar to all other samples analyzed. Seasonal variations of BCC could also be detected in the dendrogram at both sites. In Cluster 2, samples collected during December to February formed a separate subcluster, while samples collected from May to October formed another. In Cluster 1, 3 subclusters were formed. Samples from January to March were more similar than other samples.

\section{Major environmental variables regulating $\mathrm{BCC}$}

In the present study, $47.0 \%$ of the total inertia of the species data could be explained by the 14 environmental factors in primary RDA. The percentage of cumulative variance of the first 2 axes was $31.7 \%$, accounting for $38.8 \%$ of the relationship between species and environments. The forward selection with the Monte Carlo permutation test indicated that 4 variables were significantly related to BCC $(\mathrm{p}<0.05)$ : Microcystis spp. biomass, chl $a$, DIP, and Turb. Fig. 7 shows the RDA ordination of BCC data in relation to these variables. DIP and Turb were the 2 main contributors to axis 1 and were negatively correlated with each other in the 2-dimensional scaling plots (Fig. 7). Most of the samples from Meiliang Bay were positively correlated with DIP, while almost all samples collected at the lake center were positively correlated with Turb. Chl a and Microcystis spp. biomass were the important contributors to axis 2. Samples collected from April to November or even December at both sites were positively correlated with chl $a$ and Microcystis spp. abundance. Negative correlations with chl a and Microcystis spp. abundance were found in samples from December to March at both sites.

\section{DISCUSSION}

\section{Use of DGGE to fingerprint bacterial assemblages}

This study is based on the use of DGGE as a method to fingerprint $\mathrm{BCC}$. Prior to processing and comparing 
the samples, several tests were performed to optimize the method and explore its reproducibility under the conditions in our laboratory. These experiments demonstrated that the bacterial assemblage of each sample has a characteristic and reproducible DGGE fingerprint (including the presence and intensity of bands), which could be reliably used to compare different samples. The high reproducibility of DGGE has been reported in many other laboratories (e.g. Riemann et al. 1999, Gafan et al. 2005). The bacterial primers GC-F341 and R907 could also amplify cyanobacterial 16S rRNA genes, and therefore some bands may have been derived from cyanobacteria. However, we believe this did not affect our results significantly because our samples were prefiltered through $3 \mu \mathrm{m}$ filters (on average, this prefiltration removed $99 \%$ of $\mathrm{chl}$ a). Thus, the number of algal cells was always several orders of magnitude below bacterioplankton numbers.

$H^{\prime}$ was applied to reflect the 16S rDNA diversity of BCC. Both the total number of DGGE bands and their relative intensities were used to calculate this diversity index. The number and intensity of bands in a DGGE gel do not necessarily give an accurate picture of the number and abundance of the corresponding species within the bacterial community. One organism may produce more than 1 DGGE band because of multiple, heterogeneous rRNA operons (Cilia et al. 1996). On the other hand, partial 16S rDNA sequences do not always allow discrimination between species, such that 1 DGGE band may represent several species with identical partial 16S rDNA sequences (Vallaeys et al. 1997). In addition, in a mixture of target rDNAs present at very different concentrations, the less abundant sequences would not be amplified sufficiently to visualize as bands on a DGGE gel. Therefore, the banding pattern reflects only the most abundant rDNA types in the microbial community (Muyzer et al. 1993). Because of these shortcomings inherent in $16 \mathrm{~S}$ rDNA DGGE, the diversity index calculated from the DGGE banding patterns of amplified 16S rDNA sequences must be interpreted only as an indication and not an absolute measure of the degree of diversity in a bacterial community.

\section{Impact of eutrophication on BCC}

UPGMA and RDA results showed that spatial and temporal variations were inherent within $\mathrm{BCC}$ and that different environmental variables were correlated with the variations in $\mathrm{BCC}$ at 2 sites in the same lake. The potential relationship between the explanatory environmental variables and $\mathrm{BCC}$ is discussed below.
Nutrient concentration and composition may directly influence bacterial biomass as well as community composition through effects on growth (Haukka et al. 2006). Elemental ratios of different fractions (e.g. total, in seston, bacterial size class) have been widely used to estimate nutrient limitation. Different authors have used different criteria to define nutrient deficiency. For bacterioplankton, Elser et al. (1995) reported an N/P ratio of 40 to 50 as a threshold below which bacteria take up nitrogen and above which they release it. In our study, the lowest ratios of DIN/DIP were close to 200, which indicated a severe deficiency of DIP in the water column. DIP is quickly depleted when the biomass of plankton increases heavily during late spring and summer. Other forms of $\mathrm{P}$ cause stress and growth rate limitation when more easily utilized compounds such as DIP are depleted (Kisand et al. 2001). Although algae and bacteria produce alkaline phosphatases in order to use organic forms of $\mathrm{P}$ (Pettersson 1980), this could not immediately compensate the effects of DIP depletion until the biomass of plankton began to decrease (Fig. 3). Several studies have shown that bacterioplankton could be inhibited by inorganic nutrients, particularly by P (e.g. Coveney \& Wetzel 1992). According to the long-term average of nutrients in Lake Taihu, deficiency of DIP could play an important role in regulating $\mathrm{BCC}$, especially in Meiliang Bay, which always harbors a high density of plankton (Gao et al. 2006).

High levels of phytoplankton biomass and chl a concentration were another reflection of eutrophication in the water body (Chen et al. 2003). RDA results indicated that both the biomass of Microcystis spp. and chl a were significantly correlated with the variations in BCC. Although Microcystis spp. biomass might have a certain correlation with the concentration of chl $a$, neither of the inflation factors exceeded 20 in our RDA model (ter Braak \& Šmilauer 2002). Close relationships between bacteria and phytoplankton have often been reported in aquatic systems maintaining high phytoplankton biomass (e.g. Pinhassi et al. 2004, Rooney-Varga et al. 2005). Phytoplankton release up to $25 \%$ of the total organic carbon fixed by photosynthesis into the surrounding 'phycosphere,' or region immediately surrounding and influenced by algal cells (Doucette 1995). The dissolved organic matter is then rapidly consumed and remineralized by the bacterial community (Jensen 1983). There is also some evidence that differences in the quality of organic matter produced by different types of phytoplankton cause shifts in the species composition of bacterial communities utilizing this organic matter (van Hannen et al. 1999). 


\section{Influence of water turbidity on BCC}

RDA results indicated that water turbidity was a significant environmental variable correlated with variations in BCC. Water turbidity is a rough measure of water transparency, which itself represents a combination of several different causes (Yannarell \& Triplett 2005). The identification of water turbidity as important in the model does not suggest an immediate mechanistic explanation for variations in BCC. In the present study, the significant correlation between chl a concentration and water turbidity indicated that phytoplankton is the main contributor to water turbidity in Meiliang Bay (Fig. 2a). No evident correlation was found between chl $a$ and water turbidity in the lake center. A previous study reported that in the lake center, moderate wind ( 3.3 to $5.0 \mathrm{~m} \mathrm{~s}^{-1}$ ) could cause strong mixing of the water column and sediment resuspension during almost two-thirds of the year (Zhang et al. 2003). Resuspended sediment was the major cause for high water turbidity at this site.

The active resuspension of bottom sediments into the water column is a common feature of large shallow lakes and represents a major physical factor in such ecosystems. Wind-induced water column mixing can theoretically have a positive (enhanced growth/biomass) or negative (reduced growth/biomass) impact on bacterioplankton dynamics (Kisand \& Nõges 2004). Under these conditions, the upper layer of sediment is continuously resuspended into the water column. The fluxes of organic and inorganic matter between sediment and the water column are presumably high, and nutrients may be effectively transported into the water column. In addition, the flux of sediment bacteria on sediment particles is not a rare event, and the pelagic bacterial community may be a mixture of species primarily from the sediment and/or water column. A negative effect can occur due to the inhibition of bacterial growth (or other planktonic organisms) by very intensive mixing and resuspension under conditions of high physical forces. Unfortunately, we have no data on biomass, productivity of the sediment, or fluxes of bacteria between the sediment and the water column. However, when RDA was performed with water turbidity removed from the pool of available environmental variables, DOC (data not shown) consistently replaced it in the model. Thus, it is likely that the effect of water turbidity properly reflected a composite effect of all sources of variation, but it was particularly associated with variables relating to the quantity and quality of carbon in the water.

In addition, the abundances of ciliates, rotifers, or cladocerans showed no significant correlations with the variations in BCC in our RDA model. These results do not imply that top-down control is not important in determining bacterial community composition in this lake. From this study, we can only conclude that topdown factors do not relate to seasonal changes in the structure of the bacterial community. Similar results were also shown in other research. Muylaert et al. (2002) found no evidence for top-down regulation of bacterial community composition in turbid lakes, while grazing by ciliates and daphnids was significantly related to changes in the bacterial community in clearwater lakes. Their results also indicated that bacterial community composition was related to phytoplankton biomass in high-nutrient lakes. Therefore, we presume that in eutrophic shallow lakes, the seasonality of bacterial community structure would mainly depend on the dominant substrate source.

In the present study, we have shown that the variations in BCC and its environmental factors were highly correlated. Among the 14 selected environmental variables, the biomass of Microcystis spp., chl a, inorganic phosphorus, and water turbidity were most significantly correlated with the bacterioplankton DGGE patterns. Site-specific differences in wind-induced sediment resuspension, as well as differences in intensity of eutrophication, were identified as major causes for the observed heterogeneity within habitats. However, the extent to which variations in bacterial community structure underlie specific environmental conditions is still uncertain. These data stress the need for studying the physiological taxa of bacterioplankton by culture, or culture-independent methods, so that the significance of their ecosystem roles may be determined.

Acknowledgements. We thank Dr. Q. L. Wu and Dr. G. Gao for providing valuable advice. Dr. H. S. Cao, M. Zhang, and $\mathrm{X}$. D. Wu provided much appreciated field support during the sampling period. The Chinese State Key Basic Research and Development Plan (No. 2002CB412305), the National Natural Science Foundation of China (No. 40471045), and the OneHundred-Scientists Program of the CAS supported this research.

\section{LITERATURE CITED}

Chen Y, Qin B, Teubner K, Dokulil MT (2003) Long-term dynamics of phytoplankton assemblages: Microcystisdomination in Lake Taihu, a large shallow lake in China. J Plankton Res 25:445-453

Cilia V, Lafay B, Christen R (1996) Sequence heterogeneities among 16S ribosomal RNA sequences, and their effect on phylogenetic analyses at the species level. Mol Biol Evol 13:451-461

Cotner JB, Biddanda BA (2002) Small player, large role: microbial influence on biogeochemical processes in pelagic aquatic ecosystems. Ecosystems 5:105-121

Coveney MF, Wetzel RG (1992) Effects of nutrients on specific growth rate of bacterioplankton in oligotrophic lake water cultures. Appl Environ Microbiol 58:150-156 
Doucette GJ (1995) Interactions between bacteria and harmful algae: a review. Nat Toxins 3:64-74

Elser JJ, Chrzanowski TH, Sterner RW, Schampel JH, Foster DK (1995) Elemental ratios and uptake and release of nutrients by phytoplankton and bacteria in three lakes of the Canadian shield. Microb Ecol 29:145-162

Gafan GP, Lucas VS, Roberts GJ, Petrie A, Wilson M, Spratt DA (2005) Statistical analyses of complex denaturing gradient gel electrophoresis profiles. J Clin Microbiol 43:3971-3978

Gao G, Zhu G, Qin B, Chen J, Wang K (2006) Alkaline phosphatase activity and the phosphorus mineralization rate of Lake Taihu. Sci China Ser D: Earth Sci 49(Suppl 1): 176-185

Haukka K, Kolmonen E, Hyder R, Hietala J, Vakkiainen K, Kairesalo T, Haario H, Sivonen K (2006) Effect of nutrient loading on bacterioplankton community composition in lake mesocosms. Microb Ecol 51:137-146

Hu H, Li Y, Wei Y, Zhu H, Chen J, Shi Z (1980) Freshwater algae in China. Shanghai Science and Technology Press, Shanghai (in Chinese)

Huang X (1999) Survey, observation and analysis of lake ecology. Standard Press of China, Beijing (in Chinese)

Jensen LM (1983) Phytoplankton release of extracellular organic carbon, molecular weight composition, and bacterial assimilation. Mar Ecol Prog Ser 11:39-48

Kisand V, Nõges T (2004) Abiotic and biotic factors regulating dynamics of bacterioplankton in a large shallow lake. FEMS Microbiol Ecol 50:51-62

Kisand V, Tuvikene L, Nõges T (2001) Role of phosphorus and nitrogen for bacteria and phytoplankton development in a large shallow lake. Hydrobiologia 457:187-197

Lindström ES, Bergström A (2005) Community composition of bacterioplankton and cell transport in lakes in two different drainage areas. Aquat Sci 67:210-219

Liu GC, Li DS, Dong SL (2000) A study on bacterioplankton productivity of experimental shrimp polyculture enclosures. Acta Ecol Sin 20:124-128 (in Chinese)

Muylaert K, Van der Gucht K, Vloemans N, De Meester L, Gillis M, Vyverman W (2002) Relationship between bacterial community composition and bottom-up versus topdown variables in four eutrophic shallow lakes. Appl Environ Microbiol 68:4740-4750

Muyzer G, De Waal EC, Uitterlinden AG (1993) Profiling of complex microbial populations by denaturing gradient gel electrophoresis analysis of polymerase chain reactionamplified genes coding for 16S rRNA. Appl Environ Microbiol 59:695-700

Pettersson K (1980) Alkaline phosphatase activity and algal surplus phosphorus as phosphorus-deficiency indicators in Lake Erken. Arch Hydrobiol Beih 89:54-87

Pinhassi J, Sala MM, Havskum H, Peters F, Guadayol Ò, Maltis A, Marrasé C (2004) Changes in bacterioplankton composition under different phytoplankton regimens. Appl Environ Microbiol 70:6753-6766

Porter KG, Feig YS (1980) The use of DAPI for identifying and

Editorial responsibility: Jed Fuhrman,

Los Angeles, California, USA counting aquatic microflora. Limnol Oceanogr 25:943-948

Qin B, Hu W, Chen W (eds) (2004) Process and mechanism of environmental changes of Lake Taihu. Science Press, Beijing (in Chinese)

Riemann L, Steward GF, Fandino LB, Campbell L, Landry MR, Azam F (1999) Bacterial community composition during two consecutive NE monsoon periods in the Arabian Sea studied by denaturing gradient gel electrophoresis (DGGE) of rRNA genes. Deep-Sea Res 46:1791-1811

Rooney-Varga JN, Giewat MW, Savin MC, Sood S, LeGresley M, Martin JL (2005) Links between phytoplankton and bacterial community dynamics in a coastal marine environment. Microb Ecol 49:163-175

Schauer M, Balagué V, Pedrós-Alió C, Massana R (2003) Seasonal changes in the taxonomic composition of bacterioplankton in a coastal oligotrophic system. Aquat Microb Ecol 31:163-174

Shannon CE, Weaver W (1971) The mathematical theory of communication. University of Illinois Press, Urbana, IL

Somerville CC, Knight IT, Straube WL, Colwell RT (1989) Simple, rapid method for direct isolation of nucleic acids from aquatic environments. Appl Environ Microbiol 55: $548-554$

Tammert H, Kisand V, Nõges T (2005) Bacterioplankton abundance and activity in a small hypertrophic stratified lake. Hydrobiologia 547:83-90

ter Braak CJF, Šmilauer P (2002) CANOCO reference manual and CanoDraw for Windows user's guide to CANOCO Windows. Microcomputer Power, Ithaca, NY

Vallaeys T, Topp E, Muyzer G, Macheret V, Laguerre G, Rigaud A, Soulas G (1997) Evaluation of denaturing gradient gel electrophoresis in the detection of $16 \mathrm{~S}$ rDNA sequence variation in rhizobia and methanotrophs. FEMS Microbiol Ecol 24:279-285

van Hannen EJ, Mooij W, van Agterveld MP, Gons HJ, Laanbroek HJ (1999) Detritus-dependent development of the microbial community in an experimental system: qualitative analysis by denaturing gradient gel electrophoresis. Appl Environ Microbiol 65:2478-2484

Velji MI, Albright LJ (1993) Improved sample preparation for enumeration of aggregated aquatic substrate bacteria. In: Kemp PF, Sherr BF, Sherr EB, Cole JJ (eds) Handbook of methods in aquatic microbial ecology. Lewis Publishers, Boca Raton, FL, p 139-142

Wu Q, Chen Y, Xu K, Liu Z, Hahn MW (2007) Intra-habitat heterogeneity of microbial food web structure under the regime of eutrophication and sediment resuspension in the large subtrophical shallow Lake Taihu, China. Hydrobiologia 581:241-254

Yannarell AC, Triplett EW (2005) Geographic and environmental sources of variation in lake bacterial community composition. Appl Environ Microbiol 71:227-239

Zhang Y, Qin B, Chen W, Hu W, Yang D (2003) Distribution, seasonal variation and correlation of the transparency in Taihu Lake. Trans Oceanol Limnol 2:31-36 (in Chinese)

Submitted: November 27, 2006; Accepted: May 7, 2007

Proofs received from author(s): July 4, 2007 